\title{
Pengaruh Perbandingan Puree Belimbing Manis (Averrhoa carambola L.) Dan Dami Nangka (Artocarpus heterophyllus L.) Terhadap Karakteristik Fruit Leather
}

\author{
The Effect of the Comparison Sweet Star Fruit Puree (Averrhoa carambola L.) and
} Jackfruit Straw (Artocarpus heterophyllus L.) on the Characteristics of Fruit Leather

\author{
Ita $^{1}$, N.L. Ari Yusasrini ${ }^{1 *}$, I Gusti Ayu Ekawati ${ }^{1}$ \\ Program Studi Teknologi Pangan, Fakultas Teknologi Pertanian, Universitas Udayana \\ Kampus Bukit Jimbaran, Badung-Bali \\ *Penulis korespondensi: N.L. Ari Yusasrini, Email: ariyusasrini@unud.ac.id
}

\begin{abstract}
This study aims to determine the effect of the comparison of sweet star fruit puree and jackfruit straw on the characteristics of fruit leather and find the comparison of sweet star fruit puree and jackfruit straw to produce fruit leather with the best characteristics. This research used Completely Randomized Design (CRD) with a comparison treatment of sweet star fruit puree and jackfruit straw as treatments consisting of 5 levels, namely comparison of 95\% sweet star fruit puree : 5\% jackfruit straw (P1), 90\% sweet star fruit puree : 10\% jackfruit straw (P2), $85 \%$ sweet star fruit puree : $15 \%$ jackfruit straw (P3), $80 \%$ sweet star fruit puree : $20 \%$ jackfruit straw (P4), $75 \%$ sweet star fruit puree : $25 \%$ jackfruit straw (P5). Each treatment was repeated 3 times resulting in 15 experimental units. The parameters observed included water content, ash content, crude fiber content, pectin content, vitamin $\mathrm{C}$ content, total sugar, and sensory properties including color, texture, flavor, taste and overall acceptance. The data generated is then analyzed with Analysis of Variance method and if the treatment affects the observed parameters, followed by the Duncan Multiple Range Test (DMRT). The results showed that the comparison of sweet star fruit puree and jackfruit straw affected the water content, ash content, crude fiber content, pectin content, vitamin C content, color, texture and flavor test. Comparison of $75 \%$ sweet star fruit puree : $25 \%$ jackfruit straw produce the best characteristic fruit leather with water content characteristics of $10,85 \%$, ash content of $0,86 \%$, crude fiber content of 3,42\%, pectin content of 3,03\%, vitamin C content 3,68 mg AAE / g, total sugar 82,37\%, brownish yellow color and preferred, slightly clay and neutral texture, taste, flavor and overall acceptance are preferred.
\end{abstract}

Keywords : fruit leather, sweet star fruit, jackfruit straw.

\section{PENDAHULUAN}

Belimbing manis merupakan buah lokal yang tersedia dalam berbagai musim, mudah ditemui di pasar tradisional dan modern, serta hargannya dapat dijangkau oleh kalangan masyarakat. Belimbing manis mempunyai nama ilmiah Averrhoa carambola L. memiliki kandungan gizi yang baik bagi tubuh. Menurut Narain, dkk. (2001) kandungan gizi dalam $100 \mathrm{~g}$ belimbing manis adalah karbohidrat 7,7 $\mathrm{g}$, protein $0,5 \mathrm{~g}$, lemak $0,7 \mathrm{~g}$, serat kasar $0,90 \mathrm{~g}$ dan vitamin C 35 g. Kandungan vitamin C yang tinggi pada belimbing manis bermanfaat sebagai antioksidan yang berfungsi untuk mencegah radikal bebas dan mencegah penyebaran sel-sel kanker, meningkatkan daya tahan tubuh dan mencegah sariawan. Penelitian Panjaitan (2014) menunjukkan bahwa belimbing manis mempunyai potensi sebagai diuretik dan antihipertensi.

Upaya divesifikasi produk olahan belimbing manis kurang mendapat perhatian dari 
masyarakat. Umumnya buah matang dikonsumsi dalam keadaan segar tanpa mengalami proses pengolahan. Apabila belimbing manis ditangani dengan baik, maka dapat meningkatkan nilai tambah serta memperpanjang masa simpan belimbing manis. Kandungan pada belimbing manis berupa pektin, gula dan asam cocok digunakan sebagai komponen dalam pembentukan gel pada suatu produk. Salah satu produk yang cocok untuk dikembangkan saat ini adalah fruit leather.

Fruit leather adalah jenis makanan yang berasal dari daging buah yang telah dihancurkan dan dikeringkan. Produk ini berbentuk lembaran tipis yang mengkilap seperti kulit buah, dengan tekstur yang plastis dan kenyal, rasanya manis tetapi masih memiliki ciri rasa khas buah yang digunakan. Fruit leather yang baik menurut Nurlaely (2002) adalah memiliki kandungan air sebesar $10-20 \%$, nilai $a W$ kurang dari 0,7 dan bertekstur liat. Fruit leather mempunyai keuntungan tertentu yaitu masa simpan yang cukup lama, mudah diproduksi, dan nutrisi yang terkandung dalam fruit leather tidak banyak berubah (Kwartiningsih dan Mulyati, 2005).

Menurut Nurainy dan
Koesoemawardhani (2007), buah-buahan yang baik digunakan sebagai bahan baku pembuatan fruit leather yaitu mempunyai kandungan pektin tinggi. Jumlah pektin yang ideal untuk pembentukan gel pada pembuatan fruit leather berkisar antara 0,75 -
1,5\% (Fachruddin, 1977). Pektin berfungsi sebagai pembentuk utama tekstur dan kelenturan fruit leather melalui viskositas dan kelenturan gel. Menurut Wibowo dalam Milya (2011), kandungan pektin belimbing manis sebesar $0,30 \%$, jumlah tersebut belum mencukupi kebutuhan pektin ideal pembentukan gel. Masalah yang sering timbul pada pembuatan fruit leather plastisitasnya yang kurang baik, sehingga perlu penambahan hidrokoloid seperti pektin sebagai bahan pembentuk gel dan pembentuk tekstur (Historasih, 2010). Pada penelitian Rahmawati dan Inmas (2017) fruit leather belimbing manis dengan penambahan hidrokoloid menggunakan karagenan 4,5\% menunjukkan penilaian organoleptik terhadap warna, aroma, rasa, dan tekstur agak disukai oleh panelis.

Untuk mencukupi kebutuhan pektin ideal pembentukan gel serta memperbaiki penilaian organoleptik pada fruit leather maka dalam penelitian ini dilakukan perbandingan puree belimbing manis dan dami nangka. Jika dibandingkan dengan hidrokoloid lain seperti karagenan dan gum arab, pektin dari dami nangka bersumber dari bahan pangan alami yang belum mengalami proses pengolahan serta lebih ekonomis karena dami nangka termasuk jenis limbah. Menurut Tarmizi (2011), dami nangka memiliki kandungan pektin sebesar 2,38\%. Menurut Fortuna (2001), dami nangka digunakan sebagai bahan tambahan dalam pembuatan fruit leather juga akan 
menghasilkan aroma khas terhadap fruit leather. Berdasarkan beberapa hal tersebut, maka perlu dilakukan penelitian mengenai pengaruh perbandingan puree belimbing manis dan dami nangka pada fruit leather. Penggunaan dami nangka dalam penelitian ini juga dapat mengoptimalkan pemanfaatan pektin alami, pemanfaatan limbah dami nangka, upaya meningkatkan nilai gizi, meningkatkan aroma pada fruit leather serta penganekaragaman produk hortikultura khususnya belimbing manis dan dami nangka. Tujuan penelitian ini adalah untuk mengetahui pengaruh perbandingan puree belimbing manis dan dami nangka terhadap karakteristik fruit leather dan untuk menentukan perbandingan puree belimbing manis dan dami nangka yang tepat sehingga mampu menghasilkan fruit leather dengan karakteristik terbaik.

\section{METODE PENELITIAN}

\section{Tempat dan Waktu Penelitian}

Penelitian ini dilaksanakan di Laboratorium Analisis Pangan, Laboratorium Pengolahan Pangan, Laboratorium Biokimia dan Nutrisi, serta Laboratorium Rekayasa Proses dan Pengendalian Mutu Fakultas Teknologi Pertanian Universitas Udayana. Pelaksanaan penelitian ini dilakukan mulai bulai Desember 2019 sampai dengan bulan Februari 2020.

\section{Bahan dan Alat}

Bahan yang digunakan dalam penelitian ini adalah limbah dami nangka (Artocarpus heterophyllus L.) jenis nangka salak (diperoleh dari pedagang buah di Jalan Teuku Umar Barat) yang berumur satu hari, buah belimbing manis varietas Belimbing Bangkok (Averrhoa carambola L.) dengan kriteria matang yang diperoleh dari toko buah di Jalan Gunung Soputan, Denpasar, gula pasir merek "Gulaku" dan asam sitrat yang dibeli dari UD. Feny, Denpasar, aquades, reagen anthrone, larutan glukosa standar, $\mathrm{H}_{2} \mathrm{SO}_{4}, \mathrm{NaOH}$, alkohol 96\%, sodium fosfat, ammonium molibdat, indikator phenolptalein, asam asetat, kalsium klorida, asam askorbat, $\mathrm{HCl}$.

Alat yang digunakan dalam proses pembuatan fruit leather adalah pisau, sendok, kompor gas (Rinnai), panci, blender (Miyako), oven, baskom, termometer, loyang $15 \times 10 \times 3 \mathrm{~cm}$, kertas roti, timbangan analitik (Shimadzu) dan timbangan digital (ACIS). Sedangkan alat untuk analisa antara lain oven (Memmert), cawan, desikator, timbangan analitik (Shimadzu), timbangan digital (ACIS), tanur, erlenmeyer (Pyrex), alumunium foil (Klin Pak), tabung reaksi, spatula, pipet mikro (Socorex), pipet volume (Pyrex), tip, pompa karet, corong, kertas saring, kertas Whatman no. 4 \& 42, waterbath, gelas beker (Pyrex), labu takar (Pyrex), gelas ukur (Pyrex), vortex (Maxi Mix II Type 367000) dan spektrofotometer UV-Vis (Biochrom). 


\section{Rancangan Percobaan}

Rancangan yang digunakan pada penelitian ini adalah Rancangan Acak Lengkap (RAL) dengan perlakuan yaitu perbandingan puree belimbing manis : dami nangka dengan 5 taraf sebagai berikut : P1 $=95 \%: 5 \% ; \mathrm{P} 2=90 \%: 10 \% ; \mathrm{P} 3=85 \%$ : $15 \%$; P4 $=80 \%: 20 \%$; P5 $=75 \%: 25 \%$. Perbandingan puree dami nangka yang digunakan berdasarkan pada total berat puree belimbing manis dan puree dami nangka. Masing-masing perlakuan diulang sebanyak 3 kali ulangan sehingga diperoleh 15 unit percobaan.

\section{Pelaksanaan Penelitian}

Proses pembuatan fruit leather yang dilakukan pada penelitian ini merujuk pada penelitian yang telah dilakukan Dhia, dkk. (2018) yang dimodifikasi. Proses pembuatan fruit leather dibagi menjadi beberapa tahapan yaitu pembuatan puree belimbing manis, pembuatan puree dami nangka dan pembuatan fruit leather.

\section{Pembuatan Puree Belimbing Manis}

Belimbing manis dibersihkan dengan menghilangkan bijinya kemudian dicuci dan dipotong-potong. Selanjutnya ditimbang $100 \mathrm{~g}$ kemudian dilanjutkan proses steam blanching pada suhu $60^{\circ} \mathrm{C}$ selama 2 menit. Buah belimbing selanjutnya dihaluskan menggunakan blender dengan ditambahkan air $50 \mathrm{ml}$ sampai menjadi puree belimbing manis.

\section{Pembuatan Puree Dami Nangka}

Dami nangka dicuci dan ditimbang $100 \mathrm{~g}$ selanjutnya di blanching dengan cara direbus dengan suhu $60^{\circ} \mathrm{C}$ selama 2 menit lalu ditiriskan. Selanjutnya dami nangka dihaluskan menggunakan blender dengan ditambahkan air $50 \mathrm{ml}$ sampai menjadi puree dami nangka.

\section{Pembuatan Fruit Leather}

Puree belimbing manis dan puree dami nangka sesuai perlakuan dengan berat total 100 gram ditambahkan gula $20 \mathrm{~g}$ dan asam sitrat $0,25 \mathrm{~g}$, selanjutnya dipanaskan dengan kemudian dituang dalam loyang dengan ukuran 15x10x3 cm yang sudah dilapisi kertas roti dan dicetak dengan ketebalan \pm 2 $3 \mathrm{~mm}$. Selanjutnya adonan dikeringkan menggunakan oven dengan suhu $65-70^{\circ} \mathrm{C}$ selama 8 jam. Adonan dipotong-potong dengan ukuran $8 \times 6 \mathrm{~cm}$.

\section{Variabel yang Diamati}

Variabel yang diamati dalam penelitian ini adalah kadar air dengan metode oven (AOAC, 2005), kadar abu dengan metode gravimetri (AOAC, 2005), total gula dengan metode anthrone (Andarwulan, dkk,. 2011), kadar serat kasar dilakukan dengan metode hidrolisis asam dan basa (Sudarmadji, dkk,. 1997), kadar vitamin C dengan spektrofotometri (Kannan, dkk., 2013), kadar pektin dengan metode oven (Marzuki, dkk,. 2008), serta uji sensori meliputi warna rasa, aroma, tekstur dan penerimaan keseluruhan (uji hedonik) serta warna dan tekstur (uji skoring) (Soekarto, 1985 


\section{HASIL DAN PEMBAHASAN}

\section{Analisa Bahan Baku}

Nilai rata-rata kadar air, kadar abu, kadar serat kasar, kadar pektin, kadar vitamin $\mathrm{C}$ dan total gula dari puree belimbing manis dan puree dami nangka dapat dilihat pada Tabel 2. Menurut Nurainy dan Koesoemawardani (2007) bahan baku yang baik dalam pembuatan fruit leather harus mengandung pektin yang cukup tinggi. Tabel 2 menunjukkan kandungan pektin dalam puree belimbing manis pada bahan baku sebesar $0,65 \%$. Jumlah tersebut belum cukup untuk memenuhi syarat dalam pembentukan gel pada pembuatan fruit leather yaitu sebesar 0,75-1,5\%, sedangkan kandungan pektin pada puree dami nangka sebesar 2,29\%. Hal tersebut menunjukkan bahwa puree dami nangka memenuhi syarat untuk mencukupi kebutuhan pektin ideal dalam pembentukan gel pada pembuatan fruit leather.

Tabel 2. Nilai rata-rata kadar air, kadar abu, kadar serat kasar, kadar pektin, kadar vitamin $\mathrm{C}$ dan total gula dari puree belimbing manis dan dami nangka.

\begin{tabular}{lcc}
\hline Komponen & $\begin{array}{c}\text { Puree Belimbing } \\
\text { Manis }\end{array}$ & $\begin{array}{c}\text { Puree Dami } \\
\text { Nangka }\end{array}$ \\
\hline Air (\%) & $85,69 \pm 0,57$ & $60,98 \pm 0,08$ \\
Abu (\%) & $1,18 \pm 0,09$ & $0,70 \pm 0,01$ \\
Serat Kasar (\%) & $0,90 \pm 0,02$ & $3,21 \pm 0,28$ \\
Pektin (\%) & $0,65 \pm 0,04$ & $2,29 \pm 0,01$ \\
Vitamin C (mg/g) & $2,66 \pm 0,05$ & $1,59 \pm 0,03$ \\
Total Gula (\%) & $75,77 \pm 0,85$ & $48,04 \pm 0,21$ \\
\hline
\end{tabular}

\section{Analisa Karakteristik Kimia}

\section{Kadar Air}

Berdasarkan hasil sidik ragam menunjukkan bahwa perbandingan puree belimbing manis dan dami nangka berpengaruh nyata $(\mathrm{P}<0,05)$ terhadap kadar air fruit leather. Tabel 3 menunjukkan kadar air tertinggi terdapat pada perbandingan $95 \%$ puree belimbing manis : 5\% dami nangka (P1) yaitu sebesar $12,92 \%$, sedangkan kadar air terendah pada perbandingan $75 \%$ puree belimbing manis : 25\% dami nangka (P5) yaitu sebesar $10,85 \%$. Hal ini menunjukkan semakin banyak puree belimbing manis dan semakin sedikit puree dami nangka maka kadar air pada fruit leather semakin meningkat .

Tinggi rendahnya kadar air dapat dipengaruhi oleh beberapa hal diantaranya kandungan pektin, serat dan gula. Pada penelitian ini puree dami nangka berfungsi sebagai penyumbang pektin untuk membentuk gel dari fruit leather. Menurut Fardiaz (1989), pembentukan gel merupakan suatu penggabungan atau pengikatan silang rantai-rantai polimer sehingga terbentuk suatu jala tiga dimensi bersambungan, selanjutnya jala ini menangkap air di dalam bahan dan 
membentuk struktur yang kuat dan kaku sehingga air bebas relatif sedikit dan menyebabkan kadar airnya menurun. Kandungan serat dalam puree dami nangka yang lebih banyak dibandingkan puree belimbing manis menyebabkan air yang terikat didalamnya juga semakin banyak. Serat memiliki sifat yang mampu mengikat air dalam bahan (Lubis, dkk., 2014). Penambahan gula dalam pembuatan fruit leather juga memberikan pengaruh terhadap kadar air. Gula merupakan senyawa higroskopis yang mampu mengikat air bebas menjadi air terikat yang akan sulit diuapkan saat pemanasan. Menurut SNI No.1718 tentang manisan kering kadar air maksimal adalah 25\%, maka semua perlakuan pada produk fruit leather belimbing manis ini sudah memenuhi SNI manisan kering yang ditentukan.

\section{Kadar Abu}

Berdasarkan hasil sidik ragam menunjukkan bahwa perbandingan puree belimbing manis dan dami nangka berpengaruh nyata $(\mathrm{P}<0,05)$ terhadap kadar abu fruit leather. Tabel 3 menunjukkan kadar abu tertinggi terdapat pada perbandingan $75 \%$ puree belimbing manis : 25\% dami nangka (P5) yaitu sebesar $1,37 \%$, sedangkan kadar abu terendah pada perbandingan 95\% puree belimbing manis : 5\% dami nangka (P1) yaitu sebesar $0,86 \%$. Hal ini menunjukkan bahwa semakin sedikit puree belimbing manis dan semakin banyak puree dami nangka maka kadar abu pada fruit leather semakin meningkat.

Kandungan mineral pada masingmasing bahan mempengaruhi kadar abu yang dihasilkan (Sheilla, dkk. 2017). Kandungan mineral belimbing manis lebih rendah dibandingkan nangka, yaitu kalsium $8,00 \mathrm{mg}$, fosfor $22,00 \mathrm{mg}$ dan besi $0,80 \mathrm{~g}$ (Narain, dkk. 2001) sedangkan kandungan mineral nangka sebesar, kalsium 20,0 mg, fosfor $38,41 \mathrm{mg}$, besi $0,5 \mathrm{mg}$ (USDA, 2013). Menurut Winarno (2008) kadar abu adalah unsur mineral atau zat anorganik yang tidak terbakar pada saat pembakaran. Hasil proses pembakaran atau pengabuan yang dilakukan menyebabkan zat organik pada fruit leather terbakar, namun zat anorganik atau unsur mineral yang ada pada fruit leather seperti kalsium, fosfor dan zat besi yang terdapat pada fruit leather tidak terbakar.

\section{Serat Kasar}

Berdasarkan hasil sidik ragam menunjukkan bahwa perbandingan puree belimbing manis dan dami nangka berpengaruh nyata $(\mathrm{P}<0,05)$ terhadap kadar serat kasar fruit leather. Tabel 3 menunjukkan kadar serat kasar tertinggi terdapat pada perbandingan $75 \%$ puree belimbing manis : 25\% dami nangka (P5) yaitu sebesar $3,42 \%$, sedangkan kadar serat kasar terendah pada perbandingan 95\% puree belimbing manis : 5\% dami nangka (P1) yaitu sebesar 1,34\%. Hal ini 
menunjukkan bahwa semakin sedikit puree belimbing manis dan semakin banyak puree dami nangka maka kadar serat kasar pada fruit leather semakin meningkat.

Meningkatnya kadar serat kasar pada fruit leather dipengaruhi oleh kadar serat kasar pada puree dami nangka yaitu sebesar $3,21 \%$ lebih tinggi dari belimbing manis yaitu sebesar 0,90\%. Perbandingan puree dami nangka dalam penelitian ini berfungsi sebagai gelling agent karena mengandung pektin cukup tinggi yakni sebesar 2,38\% (Tarmizi, 2011). Menurut Winarno (2004), pektin merupakan heteropolisakarida yang dapat mempengaruhi peningkatan kadar serat kasar karena heteropolisakarida merupakan polisakarida yang dapat memperkuat tekstur yang tidak dapat dicerna tubuh tetapi merupakan serat pangan yang dapat menstimulasi enzim-enzim pencernaan.

Tabel 3. Nilai rata-rata kadar air, kadar abu, dan kadar serat kasar fruit leather belimbing manis dengan perbandingan puree dami nangka

\begin{tabular}{|c|c|c|c|}
\hline $\begin{array}{c}\text { Perlakuan } \\
\text { (Puree Belimbing Manis : } \\
\text { Puree Dami Nangka) }\end{array}$ & $\begin{array}{c}\text { Kadar Air } \\
(\%)\end{array}$ & $\begin{array}{c}\text { Kadar Abu } \\
(\%)\end{array}$ & $\begin{array}{c}\text { Kadar Serat Kasar } \\
(\%)\end{array}$ \\
\hline P1 (95\%: 5\%) & $12,92 \pm 0,19 \mathrm{c}$ & $0,86 \pm 0,07 \mathrm{a}$ & $1,34 \pm 0,30 \mathrm{a}$ \\
\hline P2 (90\% : 10\%) & $12,34 \pm 0,60 \mathrm{bc}$ & $0,89 \pm 0,07 \mathrm{a}$ & $1,79 \pm 0,47 \mathrm{a}$ \\
\hline P3 (85\% : 15\%) & $12,18 \pm 0,56 \mathrm{bc}$ & $0,91 \pm 0,21 \mathrm{a}$ & $2,58 \pm 0,13 b$ \\
\hline P4 (80\% : 20\%) & $11,58 \pm 0,24 \mathrm{ab}$ & $1,19 \pm 0,03 \mathrm{~b}$ & $2,86 \pm 0,13 \mathrm{bc}$ \\
\hline P5 (75\%: 25\%) & $10,85 \pm 0,54 \mathrm{a}$ & $1,37 \pm 0,12 \mathrm{~b}$ & $3,42 \pm 0,37 \mathrm{c}$ \\
\hline
\end{tabular}

Keterangan : Huruf yang sama dibelakang nilai rata-rata pada kolom yang sama menunjukkan berbeda tidak nyata $(\mathrm{P}>0,05)$.

Tabel 4. Nilai rata-rata kadar pektin, kadar vitamin $\mathrm{C}$ dan total gula fruit leather belimbing manis dengan perbandingan puree dami nangka

\begin{tabular}{cccc}
\hline $\begin{array}{c}\text { Perlakuan } \\
\text { (Puree Belimbing Manis : } \\
\text { Puree Dami Nangka) }\end{array}$ & $\begin{array}{c}\text { Kadar Pektin } \\
(\%)\end{array}$ & $\begin{array}{c}\text { Kadar Vitamin C } \\
\text { (mg AAE/g) }\end{array}$ & $\begin{array}{c}\text { Total Gula } \\
(\%)\end{array}$ \\
\hline P1 $(95 \%: 5 \%)$ & $2,01 \pm 0,01 \mathrm{a}$ & $2,13 \pm 0,07 \mathrm{a}$ & $83,93 \pm 0,91 \mathrm{a}$ \\
P2 $(90 \%: 10 \%)$ & $2,30 \pm 0,06 \mathrm{~b}$ & $2,43 \pm 0,06 \mathrm{~b}$ & $83,45 \pm 0,46 \mathrm{a}$ \\
P3 $(85 \%: 15 \%)$ & $2,59 \pm 0,04 \mathrm{c}$ & $3,25 \pm 0,09 \mathrm{c}$ & $83,27 \pm 0,47 \mathrm{a}$ \\
P4 $(80 \%: 20 \%)$ & $2,80 \pm 0,01 \mathrm{~d}$ & $3,57 \pm 0,06 \mathrm{~d}$ & $83,09 \pm 0,92 \mathrm{a}$ \\
P5 (75\%:25\%) & $3,03 \pm 0,05 \mathrm{e}$ & $3,68 \pm 0,03 \mathrm{~d}$ & $82,37 \pm 0,97 \mathrm{a}$ \\
\hline
\end{tabular}

Keterangan : Huruf yang sama dibelakang nilai rata-rata pada kolom yang sama menunjukkan berbeda tidak nyata $(\mathrm{P}>0,05)$. 


\section{Kadar Pektin}

Berdasarkan hasil sidik ragam pada menunjukkan bahwa perbandingan puree belimbing manis dan dami nangka berpengaruh nyata $(\mathrm{P}<0,05)$ terhadap kadar pektin fruit leather. Tabel 4 menunjukkan kadar pektin tertinggi terdapat pada perbandingan $75 \%$ puree belimbing manis : $25 \%$ dami nangka (P5) yaitu sebesar 3,03\%, sedangkan kadar pektin terendah pada perbandingan $95 \%$ puree belimbing manis : $5 \%$ dami nangka (P1) yaitu sebesar $2,01 \%$. Hal ini menunjukkan bahwa semakin sedikit puree belimbing manis dan semakin banyak puree dami nangka maka kadar pektin fruit leather semakin meningkat.

Menurut Nurainy dan Koesoemawardhani (2007), fruit leather kualitas yang baik ditentukan oleh beberapa komponen yaitu pektin, serat dan asam. Pektin dan serat berfungsi sebagai pembentuk utama tekstur dan kelenturan fruit leather melalui viskositas dan kelenturan gel.

\section{Kadar Vitamin C}

Berdasarkan hasil sidik ragam menunjukkan bahwa perbandingan puree belimbing manis dan dami nangka berpengaruh nyata $(\mathrm{P}<0,05)$ terhadap kadar vitamin $\mathrm{C}$ fruit leather. Tabel 4 menunjukkan kadar vitamin C tertinggi terdapat pada perbandingan $75 \%$ puree belimbing manis : 25\% dami nangka (P5) yaitu sebesar 3,68 mg AAE/g, sedangkan kadar vitamin $\mathrm{C}$ terendah terdapat pada perbandingan $95 \%$ puree belimbing manis : 5\% dami nangka (P1) yaitu sebesar 2,13 mg AAE/g. Hal ini menunjukkan bahwa semakin banyak puree belimbing manis dan semakin sedikit puree dami nangka yang ditambahkan kadar vitamin C fruit leather semakin menurun. Penggunaan puree dami nangka berfungsi sebagai penyumbang pektin alami pada fruit leather. Pektin merupakan merupakan hidrokoloid yang memiliki kemampuan membentuk gel sehingga dapat melindungi vitamin $\mathrm{C}$ serta komponen gizi lain dari kerusakan oksidatif (Winarno, 1992). Hidrokoloid mempunyai sifat mudah mengikat molekul-molekul air juga senyawa-senyawa lain seperti vitamin $\mathrm{C}$ dan asam-asam organik sehingga senyawa yang mudah menguap dan rusak oleh proses pengolahan dapat dihambat sebagian dengan penambahan hidrokoloid (Winarno, 2004).

\section{Total Gula}

Berdasarkan hasil sidik ragam menunjukkan bahwa perbandingan puree belimbing manis dan dami nangka tidak berpengaruh nyata $(\mathrm{P}>0,05)$ terhadap total gula fruit leather. Tabel 4 menunjukkan total gula berkisar antara 82,37\% - 83,93\%. Menurut Enie dan Nami (1992), gula yang ditambahkan dalam pembuatan fruit leather dapat mencapai $30 \%$ untuk tiga macam formula buahbuahan. Namun penambahan gula dalam pembuatan fruit leather juga harus memperhatikan kadar gula buah yang digunakan. Lees dan Jackson (2004) menyatakan bahwa kadar gula reduksi 
berkaitan dengan proses inversi sukrosa menjadi gula invert (glukosa dan fruktosa).

\section{Sifat Sensori}

\section{Warna}

Berdasarkan hasil sidik ragam menunjukkan bahwa perbandingan puree belimbing manis dan dami nangka tidak berpengaruh nyata $(\mathrm{P}>0,05)$ terhadap warna pada pengujian hedonik dan berpengaruh nyata $(\mathrm{P}<0,05)$ pada pengujian skoring fruit leather. Tabel 5 menunjukkan bahwa uji hedonik warna fruit leather pada semua perlakuan disukai penelis. Tingkat kesukaan panelis terhadap warna fruit leather dapat dipengaruhi oleh warna alami pada bahan baku dimana puree dami nangka cenderung memiliki warna kuning cerah dibandingkan dengan puree belimbing manis yang cenderung kuning pucat karena belimbing manis mudah teroksidasi.

Tabel 6 menunjukkan bahwa uji skoring warna tertinggi terdapat pada perbandingan $80 \%$ puree belimbing manis : $20 \%$ dami nangka (P4) dengan kriteria warna kuning kecoklatan, sedangkan uji skoring warna terendah terdapat pada perbandingan $95 \%$ puree belimbing manis : 5\% dami nangka (P1) dengan kriteria warna coklat kekuningan. Semakin tinggi puree belimbing yang digunakan warna fruit leather akan semakin coklat. Hal ini disebabkan karena belimbing mudah mengalami proses browning (pencoklatan). Menurut Zulfahnur, dkk. (2009), salah satu faktor yang menyebabkan proses browning adalah adanya enzim polifenol oksidase yang menghasilkan pigmen berwarna coklat.

Tabel 5. Nilai rata-rata uji hedonik warna, aroma, tekstur, rasa dan penerimaan keseluruhan fruit leather

\begin{tabular}{cccccc}
\hline Perlakuan & \multicolumn{4}{c}{ Nilai Rata-Rata Uji Hedonik } \\
\cline { 2 - 6 } $\begin{array}{c}\text { Puree Belimbing } \\
\text { Manis : Dami } \\
\text { Nangka) }\end{array}$ & Warna & Tekstur & Aroma & Rasa & $\begin{array}{c}\text { Penerimaan } \\
\text { Keseluruhan }\end{array}$ \\
\hline P1 $(95 \%: 5 \%)$ & $3,72 \mathrm{a}$ & $3,80 \mathrm{ab}$ & $4,12 \mathrm{ab}$ & $3,64 \mathrm{a}$ & $3,76 \mathrm{a}$ \\
P2 $(90 \%: 10 \%)$ & $3,76 \mathrm{a}$ & $3,84 \mathrm{ab}$ & $4,16 \mathrm{ab}$ & $3,80 \mathrm{a}$ & $3,68 \mathrm{a}$ \\
P3 $(85 \%: 15 \%)$ & $3,68 \mathrm{a}$ & $3,40 \mathrm{~b}$ & $3,96 \mathrm{a}$ & $3,92 \mathrm{a}$ & $3,64 \mathrm{a}$ \\
P4 $(80 \%: 20 \%)$ & $3,84 \mathrm{a}$ & $4,00 \mathrm{a}$ & $4,04 \mathrm{a}$ & $3,64 \mathrm{a}$ & $3,60 \mathrm{a}$ \\
P5 $(75 \%: 25 \%)$ & $3,80 \mathrm{a}$ & $3,60 \mathrm{ab}$ & $4,36 \mathrm{~b}$ & $3,76 \mathrm{a}$ & $3,88 \mathrm{a}$ \\
\hline
\end{tabular}

Keterangan: Huruf yang sama dibelakang nilai rata-rata pada kolom yang sama menunjukkan berbeda tidak nyata $(\mathrm{P}>0,05)$.

Kriteria hedonik $1=$ sangat tidak suka, $2=$ tidak suka, $3=$ netral, $4=$ suka, dan $5=$ sangat suka.

\section{Tekstur}

Berdasarkan hasil sidik ragam menunjukkan bahwa perbandingan puree belimbing manis dan dami nangka berpengaruh nyata $(\mathrm{P}<0,05)$ terhadap uji hedonik tekstur dan tidak berpengaruh nyata $(\mathrm{P}>0,05)$ pada pengujian skoring fruit leather. Tabel 5 menunjukkan uj hedonik 
tekstur tertinggi terdapat pada perbandingan $80 \%$ puree belimbing manis : $20 \%$ dami nangka (P4) dengan kritera suka, sedangkan uji hedonik warna terendah terdapat pada perbandingan $85 \%$ puree belimbing manis : $15 \%$ dami nangka (P3) dengan kriteria netral. Tingkat kesukaan panelis terhadap tekstur fruit leather dipengaruhi oleh plastisitas dari fruit leather tersebut dimana semakin sedikit puree dami nangka yang digunakan maka tekstur yang dihasilkan semakin tidak plastis atau mudah patah. Tabel 6 menunjukkan bahwa uji skoring tekstur fruit leather memiliki kriteria agak liat untuk semua perlakuan. Hal tersebut dikarenakan puree belimbing manis dan puree dami nangka sama-sama memiliki kandungan pektin yang berfungsi sebagai gelling agent sehingga dapat menghasilkan tekstur liat pada fruit leather.

\section{Aroma}

Berdasarkan hasil sidik ragam menunjukkan bahwa perbandingan puree belimbing manis dan dami nangka berpengaruh nyata $(\mathrm{P}<0,05)$ terhadap aroma pada pengujian hedonik fruit leather. Tabel 5 menunjukkan nilai rata-rata tertinggi terdapat pada perbandingan $75 \%$ puree belimbing manis : $25 \%$ dami nangka (P5) dengan kriteria suka, sedangkan nilai rata-rata terendah terdapat pada perbandingan $85 \%$ puree belimbing manis : 15\% dami nangka (P3) dengan kriteria netral. Hal ini disebabkan karena puree dami nangka memiliki aroma yang sangat kuat dan khas sehingga aromanya dapat mendominasi pada produk yang dihasilkan dan para panelis menyukai aroma fruit leather yang dihasilkan.

Tabel 6. Nilai Rata-rata uji skoring warna dan tekstur fruit leather

\begin{tabular}{ccc}
\hline Perlakuan $($ Puree Belimbing & \multicolumn{2}{c}{ Nilai Rata-Rata Uji Skoring } \\
\cline { 2 - 3 } Manis : Dami Nangka) & Warna & Tekstur \\
\hline P1 $(95 \%: 5 \%)$ & $3,60 \mathrm{a}$ & $2,96 \mathrm{a}$ \\
P2 $(90 \%: 10 \%)$ & $3,80 \mathrm{a}$ & $3,04 \mathrm{a}$ \\
P3 $(85 \%: 15 \%)$ & $4,20 \mathrm{~b}$ & $3,00 \mathrm{a}$ \\
P4 $(80 \%: 20 \%)$ & $4,72 \mathrm{c}$ & $3,36 \mathrm{a}$ \\
P5 $(75 \%: 25 \%)$ & $4,60 \mathrm{c}$ & $3,36 \mathrm{a}$ \\
\hline
\end{tabular}

Keterangan: Huruf yang sama dibelakang nilai rata-rata pada kolom yang sama menunjukkan berbeda tidak nyata $(\mathrm{P}>0,05)$.

Kriteria skoring warna: $1=$ coklat tua, 2=coklat, 3=coklat kekuningan, 4=kuning kecoklatan, $5=$ kuning.

Kriteria skoring tekstur: $1=$ sangat tidak liat, $2=$ tidak liat, $3=$ agak liat, $4=$ liat, $5=$ sangat liat.

\section{Rasa}

Berdasarkan hasil sidik ragam menunjukkan bahwa perbandingan puree belimbing manis dan dami nangka tidak berpengaruh nyata
$(\mathrm{P}>0,05)$ terhadap rasa pada pengujian hedonik fruit leather. Tabel 5 menunjukkan bahwa uji hedonik rasa pada semua perlakuan disukai panelis. Perbandingan 
puree dami nangka pada fruit leather tidak mempengaruhi rasa karena dami nangka tidak memiliki rasa khas (hambar) sehingga setiap perlakuan memiliki rasa khas belimbing manis (Sarah, dkk., 2017).

\section{Penerimaan Keseluruhan}

Berdasarkan hasil sidik ragam menunjukkan bahwa perbandingan puree belimbing manis dan dami nangka tidak berpengaruh nyata $(\mathrm{P}>0,05)$ terhadap rasa pada pengujian hedonik fruit leather. Tabel 5 menunjukkan bahwa uji hedonik penerimaan keseluruhan pada semua perlakuan disukai panelis. Hal tersebut menunjukkan bahwa fruit leather dengan perbandingan puree belimbing manis dan dami nangka cukup disukai oleh panelis.

\section{Perlakuan Terbaik}

Berdasarkan analisis kimia dan sifat sensori fruit leather terbaik terpilih yaitu pada perbandingan $75 \%$ puree belimbing manis : $25 \%$ dami nangka (P5). Perlakuan P5 menjadi perlakuan terbaik dikarenakan dari penilaian analisis kimia yaitu kadar air telah memenuhi Standar Nasional Indonesia dan mempunyai kadar air terendah yang dapat memperpanjang masa simpan fruit leather. Kadar abu 1,37\%, kadar serat kasar 3,42\%, sebagai penyumbang pektin tertinggi dengan kadar pektin 3,03\%, kadar vitamin C 3,68 mg AAE/g, total gula $82,37 \%$. Berdasarkan penilaian organoleptik perbandingan $75 \%$ puree belimbing manis : 25\% dami nangka (P5) mempunyai penilaian keseluruhan disukai panelis dan mempunyai skor tertinggi yaitu 3,88 . Penilaian organoleptik secara hedonik pada perlakuan P5 mendapatkan penilaian suka terhadap seluruh atribut, sedangkan pada uji skoring P5 mempunyai warna kuning kecoklatan dan tekstur agak liat.

\section{KESIMPULAN DAN SARAN}

\section{Kesimpulan}

Perbandingan puree belimbing manis dan dami nangka berpengaruh terhadap kadar air, kadar abu, kadar serat kasar, kadar pektin, vitamin $\mathrm{C}$, uji skoring warna dengan kriteria kuning kecoklatan serta uji hedonik tekstur dengan kriteria disukai panelis. Perbandingan $75 \%$ puree belimbing manis : $25 \%$ dami nangka menghasilkan karakteristik terbaik pada pembuatan fruit leather dengan karakteristik kadar air 10,85\%, kadar abu 1,37\%, kadar serat kasar $3,42 \%$, kadar pektin 3,03\%, kadar vitamin C $3,68 \mathrm{mg} \mathrm{AAE} / \mathrm{g}$, total gula $82,37 \%$, warna kuning kecoklatan dan disukai, tekstur agak liat dan netral, rasa, aroma dan penerimaan keseluruhan disukai.

\section{Saran}

1. Untuk memperoleh fruit leather belimbing manis dengan perbandingan dami nangka yang memenuhi kriteria Standar Nasional Indonesia mengacu pada manisan kering, disarankan menggunakan perbandingan $75 \%$ puree belimbing manis : 25\% puree dami nangka dalam pembuatannya. 
2. Melakukan penelitian perbandingan puree belimbing manis : puree dami nangka dengan konsentrasi puree dami nangka yang lebih tinggi dalam pembuatan fruit leather.

\section{DAFTAR PUSTAKA}

Andarwulan, N., F. Kusnandar, dan D. Herawati. 2011. Analisis Pangan. Dian Rakyat, Jakarta.

AOAC. 2005. Official Methods of Analysis. $11^{\text {th }}$ edition. Association of Official Analytical Chemists Inc., Washington, D.C.

Dhia, S. Z., Ina, P.T., dan Jambe, A.A.G.N.A. 2018. Pengaruh Perbandingan Puree Kulit Buah Apel (Malus sylvestris Mill) Terhadap Karakteristik Fruit Leather Nanas (Ananas comosus Merr). Skripsi. Program Studi Ilmu dan Teknologi Pangan. Fakultas Teknologi Pertanian. Universitas Udayana, Bali.

Enie, A. B dan L. Nami. 1992. Penelitian Pembuatan Makanan Ringan Asal Buah-Buahan Tropis I. Pengaruh Sulfit dan Lama Penyimpanan Terhadap Mutu Fruit Leather. Warta IHP. Vol 9 No 1-2. Bogor.

Fachruddin, Lisdiana. 1997. Membuat Aneka Selai. Kanisius.Yogyakarta.

Fardiaz D. 1989. Hidrokoloid. Pusat Antar Universitas Pangan dan Gizi Institut Pertanian Bogor. Bogor.

Fortuna, D., Y. Anas dan A. Asben. 2001. Studi Pembuatan Fruit Leathers Buah Nangka (Artocarpus heterophylus Link) Dengan Beberapa Tingkat Pencampuran Jerami Nangka dan Konsentrasi Gula. Skripsi. Fakultas Pertanian Unand. Padang.

Historiasih, Reny. Z. 2010. Pembuatan Fruit Leather Sirsak Rosella. Skripsi. Fakultas Teknologi Industri. Universitas Pembangunan Nasional Veteran, Surabaya.
Kannan, R. Arumugam, R. Thangaradjou, T. and Anantharaman, P. 2013. Phytochemical Constituens Antioxsidan Properties and p-comaric Acid Analysis in Some Seagrasses. Food Research International. India.

Kwartiningsih, E. dan Mulyati. 2005. Pembuatan Fruit Leather Dari Nenas. Universitas Negeri Semarang, Semarang. Ekuilibrum, 4: 8-12.

Lees, R and E.B. Jackson. 2004. Sugar Confectionary and ChocolateManufacture. Thomson Litho Ltd., East Kilbride, Scotland, 379 p.

Lubis, S.A.M, Herla Rusmarilin dan Terip Karo-Karo. 2014. Studi Perbandingan Nenas dan Kangkung Dengan Konsentrasi Gum Arab Terhadap Mutu Fruit Leather. Universitas Sumatera Utara. Medan.

Marzuki, I., M. R. Ulluputty, S. A. Azzi, dan M. Suharman. 2008. Karakteristik Morfoekotipe dan Proksimat Pala Banda (Myristica fragrans Houtt.). Buletin Agronomi 36 : 146-152.

Milya S. 2011. Maizena Sebagai Alternatif Pengganti Pektin dalam Pembuatan Selai Belimbing (Averrhoa carambola L.) Jurnal Saintek. Vol. III, No. 1: 4451.

Narain N, PS. Bora, Holschuh HJ. dan M. Vasconcelos. 2001. Physical and Chemical Composition of Carambola Fruit (Averrhoacarambola L.) At Three Stages Of Maturity. Cienc Tecnol Aliment 3(3) : 144-148.

Nurainy, F. dan D. Koesoemawardhani. 2007. Efek Penambahan Rumput Laut Terhadap Karakteristik Leather Sirsak. http://Staff.Unila.Ac.Id/Harnowo/

Daftar-Publikasi-Ilmiah/. Diakses Tanggal 1 Agustus 2019.

Nurlaely, E. 2002. Pemanfaatan Buah Jambu Untuk Pembuatan Leather. Kajian Dari Proporsi Buah Pencampur. Skripsi. Jurusan Teknologi Hasil Pertanian. Fakultas Teknologi Pertanian. Universitas Brawijaya, Malang.

Panjaitan, R.G.P. 2014. Peningkatan Kandungan Kalium Urin Setelah Pemberian Ekstrak Sari Buah Belimbing Manis (Averrhoa carambola L.). Jurnal Veteriner. 15 (1): 108-113. 
Rahmawati dan P. Inmas. 2017. Pengaruh Penambahan Karagenan dan Proporsi Buah: Air Terhadap Sifat Fisikokimia serta Organoleptik Leather Belimbing Manis (Averrhoa carambola L.) . Universitas Brawijaya. Malang.

Sarah S, Noviar Harun dan A. Ali. 2017. Pembuatan "Fruit Leather" Buah Jeruk Manis (Citrus sinesis L.) Dengan Penambahan Dami Nangka (Artocarpus heterophyllus). Universitas Riau. Pekanbaru.

Sheilla, P.N.F., H. Faizah dan Rahmayuni. 2017. Pemanfaatan Bubur Buah Jambu Biji Putih dan Bubur Buah Pepaya Dalam Pembuatan Fruit Leather. Jurnal Fakultas Pertanian. Vol. 4, No. 2. Universitas Riau. Pekanbaru.

Soekarto, S.T. 1985. Penelitian Organoleptik Untuk Industri Pangan dan Hasil Pertanian. Bharata Karya Aksara, Jakarta.

Sudarmadji, S., B. Haryono dan E. Suhardi, 1997. Prosedur Analisa Untuk Bahan Makanan dan Pertanian Edisi Keempat. Liberty, Yogyakarta.

Tarmizi. 2011. Pengaruh Tingkat Pencampuran Daging Buah dan Dami Nangka Terhadap Mutu Selai Lembaran Nangka (Artocarpus heterophyllus) yang Dihasilkan. Skripsi. Fakultas Teknologi Pertanian Universitas Andalas. Padang.

USDA. 2013. Nutrient Database of Star Fruit.

http://www.nal.usda.gov/fnic/foodcom p/search/. Diakses Pada Tanggal 2 Juli 2020).

Winarno, F.G. 2008. Kimia Pangan dan Gizi. PT Gramedia Pustaka Utama. Jakarta.

Winarno, F.G. 1992. Kimia Pangan Dan Gizi. PT Gramedia Pustaka Utama. Jakarta.

Winarno, F.G. 2004. Kimia Pangan Dan Gizi. PT Gramedia Pustaka Utama. Jakarta.

Zulfahnur, R. Nurapriani, T. Tegar dan D. Askanovi. 2009. Mempelajari Reaksi Pencoklatan Enzimatis Pada Buah dan Sayur. Program Kreativitas Mahasiswa Institut Pertanian Bogor. Bogor. 